УДК 612.821

Світлана Швайко

Олена Дмитроца

Олександр Журавльов

\title{
Вплив хронотипу на сприйняття часових проміжків обстежуваних осіб у різний період доби
}

Вивчено рівень сприйняття коротких часових відрізків осіб юнацького віку з різним типом добової активності. Встановлено, що сприйняття часових відрізків різної тривалості в обстежуваних осіб з різним хронотипом залежить від пори доби. У вранішній період доби результати дослідження виявилися більш точнішими у групі «жайворонків»; серед обстежуваних осіб цієї групи не виявилось осіб, які б переоцінили заданий часовий відрізок. В обідню пору при сприйнятті коротших часових відрізків коефіцієнт точності був вищим у підгрупі, яку складали «жайворонки»; триваліші часові відрізки «сови» оцінили з більшою точністю. У вечірню пору доби коефіцієнт точності при сприйнятті різних часових відрізків був вищим у групі «сов»; серед «жайворонків» більшість осіб недооцінювали заданий проміжок часу.

Ключові слова: хронотип, «жайворонки», «сови», період доби, часові проміжки.

Постановка наукової проблеми та їі значення. Сприйняття часу відіграє важливу роль при орієнтації людини у довкіллі та сприяє іiі адаптації у різних ситуаціях [2]. Проблема оцінки та відновлення тривалості інтервалів часу тісно пов'язана з питаннями часової організації рухів. Загальновизнано, що на процеси сприйняття та оцінки часу впливають різні фактори: емоційний стан [1], наповненість відрізка подіями, вплив лікарських препаратів [5; 6], вік, а також тип нервової системи. Дослідження проблеми оцінки тривалості часу у психофізіології потребує детального вивчення у багатьох аспектах. Цікавим аспектом $є$ вивчення механізмів та особливостей оцінки коротких відрізків часу в осіб із різною добовою активністю. В такому аспекті ці питання досліджено недостатньо, вони мають фрагментарний характер, тому вивчення цієї проблеми актуально.

Аналіз досліджень цієї проблеми. Вивчення механізмів людського сприйняття є однією 3 найважливіших проблем психофізіології. Особливо цікаві можливості суб'єктивного сприйняття відрізків часу [2]. Сприйняття відрізків часу можна розглядати як віддзеркалення людини завдяки діяльності мозкових структур об'єктивної тривалості, швидкості, послідовності явищ дійсності [3]. Вивчають його за такими характеристиками, як точність оцінки, вимірювання, відтворення, диференціювання інтервалів часу $[4 ; 6]$.

Суб'єктивне визначення відрізків часу, як і траєкторії руху чи розташування у просторі, відносяться до складних форм сприйняття. Оцінка тривалості часових відрізків залежить від змісту діяльності: якщо часовий відрізок заповнений змістовною діяльністю, то суб'єктивно оцінюється як короткий, тобто недооцінюється; незаповнені, порожні за змістом часові відрізки оцінюються як довші, тобто переоцінюються [5]. Слід зазначити, що людина не має спеціального аналізатора, спрямованого лише на сприйняття часових відрізків. Тобто для сприйняття тривалості часових відрізків потрібне узгоджене функціонування низки структурних одиниць отримання та обробки інформації як єдиної системи.

Мета роботи - вивчення особливостей сприймання коротких проміжків часу осіб юнацького віку з різним хронотипом.

Матеріали та методи. Дослідження проводилося на 40 обстежуваних особах юнацького віку (17-21 рік), обох статей, здорових, праворуких. Усіх обстежуваних поділили на дві групи за типом хронотипу (по 20 осіб): I група - обстежувані-«сови», II група - обстежувані-«жайворонки»). Дослідження проходило у три етапи: I етап - ранок (9:00-10:00 год), II етап - обід (13:00-14:00 год), III етап - вечір (19:00-20:00 год).

Дослідження сприйняття часових проміжків (30 сек., 60 сек. та 120 сек.) здійснювалось за загальноприйнятою методикою, а саме обстежуваному пропонували визначити заданий проміжок часу без підрахунку і без використання годинника. Правильність оцінки проміжку часу визначали за допомогою секундоміра.

(С Швайко С., Дмитроича О., Журавльов О., 2015 
Точність оцінки часу визначали за формулою: $K m=A / C Ч 100$, де Кт - коефіцієнт точності оцінки часу, сек.; А - фактичний часовий інтервал, який минув 3 початку оцінювання обстежуваним заданого часового відрізку, сек.; С - часовий інтервал, запропонований для оцінки, сек. [9].

Під час аналізу результатів дослідження визначали, в якому співвідношенні до $100 \%$ перебувають коефіцієнти точності оцінки часу обстежуваного. Якщо обстежуваний мав коефіцієнт, більший за $100 \%$, то часові відрізки він недооцінював; якщо коефіцієнт був менший $100 \%$ - переоцінював. Чим ближчі коефіцієнти до $100 \%$ (80-110\%), тим вища точність оцінки коротких проміжків часу [9].

Під час оброки отриманих даних використовували загальноприйняті методи варіаційної статистики з використанням критерію Стьюдента.

Виклад основного матеріалу й обгрунтування отриманих результатів дослідження. Аналіз результатів дослідження сприйняття часових відрізків різної тривалості (30 сек., 60 сек., 120 сек.) в обстежуваних осіб з різним хронотипом залежно від етапів дослідження (ранок, обід, вечір), виявив такі особливості.

При сприйнятті часового відрізка тривалістю 30 сек. у вранішній час у «сов» фактичний час становив 33,2 $\pm 3,37$ при коефіцієнті оцінки точності $110,3 \pm 11,23$, що відповідає точному оціненню часового відрізка. Відзначимо, що 50 \% обстежуваних осіб цієї підгрупи недооцінили заданий часовий відрізок; 30 \% обстежуваних переоцінили цей часовий проміжок. У групі «жайворонків» показник фактичного часу становив $29,70 \pm 0,73$, при коефіцієнті точності $98,60 \pm 2,45$, що відповідає нормі.

При сприйнятті часового відрізка тривалістю 60 сек. у «сов» фактичний час обстежуваних становив 57,60 $\pm 1,00$ при коефіцієнті оцінки точності 95,70 $\pm 1,67$, що відповідає точному оціненню часового відрізка. Зазначимо, що не виявлено осіб, які б недооцінили чи переоцінили заданий часовий відрізок. У групі «жайворонків» фактичний час становив $60,60 \pm 1,06$, коефіцієнт точності $100,60 \pm 1,78$, що наближається до заданого часового проміжку та відповідає нормі. Загалом, серед «жайворонків» 10 \% обстежуваних осіб недооцінили цей часовий відрізок, решта - оцінили точно.

При сприйнятті часового відрізка тривалістю 120 сек. у групі «сов» фактичний час становив $122,30 \pm 2,49$ при коефіцієнті оцінки точності $102,0 \pm 2,16$, тобто відповідає нормі. Цікаво відзначити, що $10 \%$ обстежуваних осіб недооцінили заданий часовий відрізок. У групі «жайворонків» показник фактичного часу становив $119,00 \pm 1,16$, коефіцієнт точності $-98,70 \pm 1,03$, тобто наближаються до заданого часового проміжку та відповідає нормі.

Аналогічне дослідження часових проміжків упродовж другого етапу дослідження (обід) показало такі закономірності. При сприйнятті часового проміжку у 30 сек. у «сов» фактичний час становив $28,0 \pm 3,51$, а коефіцієнт точності - 92,90 $\pm 11,73$. За шкалою оцінювання $60 \%$ обстежуваних осіб недооцінили цей часовий проміжок. Водночас серед «жайворонків» у 80 \% обстежуваних осіб спостерігалось точне виконання цього тестового навантаження, у 20 \% відзначено переоцінку часового інтервалу. Загалом фактичний час становив $26,20 \pm 1,24$, коефіцієнт точності $-93,30 \pm 3,45$.

При сприйнятті часового відрізка у 60 сек. у «сов» фактичний час становив $101,60 \pm 3,96$, а коефіцієнт точності $-169,10 \pm 6,58$. За шкалою оцінювання $100 \%$ обстежуваних осіб недооцінили цей часовий проміжок. Серед «жайворонків» $30 \%$ осіб переоцінили часовий інтервал у 60 сек., решта точно виконали це тестове навантаження. Загалом фактичний час становив $48,90 \pm 0,94$, а коефіцієнт точності - 81,20 $\pm 1,51$.

При сприйнятті часового відрізка у 120 сек. удень у «сов» фактичний час становив 128,50 4 4,45, коефіцієнт точності $-106,60 \pm 3,68$. За шкалою оцінювання 50 \% обстежуваних недооцінили цей часовий проміжок. Тоді як 40 \% обстежуваних-«жайворонків» переоцінили часовий інтервал у 120 сек., решта - точно виконали це тестове навантаження (фактичний час становив $96,20 \pm 1,38$, коефіцієнт точності - 79,90 $\pm 1,14)$.

Аналіз результатів дослідження на третьому (вечірньому) етапі показав такі особливості. При оцінці часового інтервалу тривалістю 30 сек. у «сов» фактичний час сприйняття заданного часового проміжку становив $28,90 \pm 0,64$. За коефіцієнтами точності виконання завдання $(93,80 \pm 3,68)$ можна відзначити, що більшість обстежуваних осіб (90 \%) виконали це завдання точно, тоді як $10 \%$ н них переоцінили цей проміжок часу. У підгрупі «жайворонків» фактичний час сприйняття заданого часового інтервалу становив $35,20 \pm 0,73$. Показники фактичного часу зафіксовано в межах 33-40 сек. За показниками коефіцієнта точності відзначено, що 80 \% обстежуваних осіб недооцінили заданий проміжок часу, а $20 \%$ - виконали точно запропоноване тестове навантаження. 
При оцінці часового інтервалу тривалістю 60 сек. на завершальному етапі дослідження показники сприйняття часу у «сов» мали такі значення: фактичний час становив $74,40 \pm 1,54$, коефіцієнт точності $-123,50 \pm 2,57$. Зазначимо, що більшість обстежуваних $(90 \%)$ недооцінили заданий проміжок часу. У «жайворонків» фактичний час сприйняття часового інтервалу становив $52,50 \pm 0,89$. За показниками коефіцієнта точності відзначено, що 100 \% обстежуваних осіб виконали це завдання точно.

При дослідженні сприйняття часового проміжку у 120 сек. у «сов» фактичний час становив $119,70 \pm 1,39$, коефіцієнт точності - 99,50 $\pm 1,17$. За шкалою оцінювання $20 \%$ обстежуваних осіб недооцінили цей часовий проміжок, решта - виконали завдання точно. У підгрупі «жайворонків» фактичний час сприйняття цього часового інтервалу становив $96,00 \pm 9,72$, причому обстежувані виконали це завдання точно.

Аналізуючи результати першого етапу дослідження, відзначимо, що результати виявилися точнішими у підгрупі «жайворонків», серед них не виявилось осіб, які б переоцінили заданий часовий відрізок (рис. 1).

Аналіз результатів спостереження на другому етапі мав такі закономірності: при сприйнятті коротших часових відрізків, коефіцієнт точності був вищим у підгрупі, яку складали «сови» (див. рис. 1). Слід відзначити, що при сприйнятті часового інтервалу у 60 сек. 100 \% обстежуваних-»сов» недооцінили цей часовий інтервал.

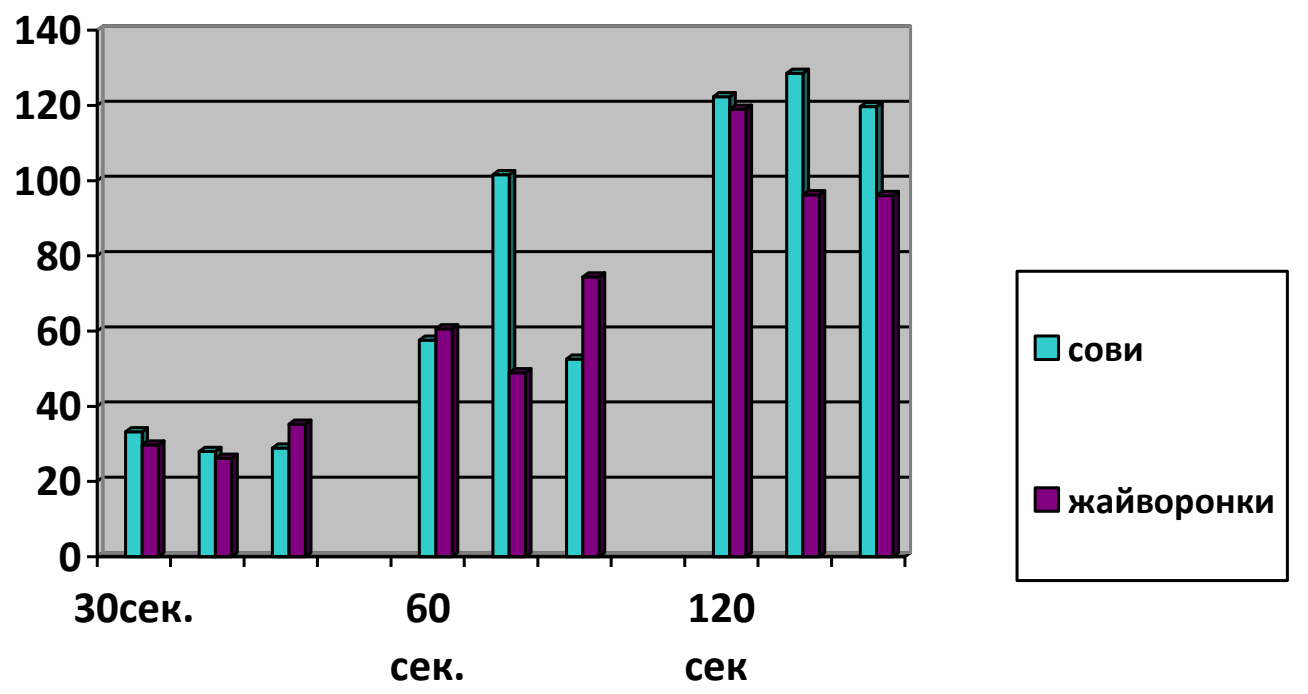

Рис. 1. Сприйняття часових відрізків обстежуваних осіб упродовж доби

Триваліші часові відрізки «сови» оцінили більш точно, ніж «жайворонки», серед яких більшість переоцінили часовий інтервал.

Аналіз результатів третього етапу дослідження показав, що коефіцієнт точності при сприйнятті різних часових відрізків був вищим у підгрупі, яку складали «сови», серед яких виявилися лише особи, схильні переоцінювати часові проміжки (див. рис. 1). У підгрупі, яку складали «жайворонки», більшість осіб недооцінювали заданий проміжок часу.

Таким чином, сприйняття часових відрізків певною мірою залежить від типу біоритму. Дані літератури зазначають, що відмірювання інтервалів відбувається за участі гіпокампу, активація якого $\epsilon$ обов'язковою умовою для фіксації в пам'яті певного часового еталону. У процесі безпосереднього здійснення діяльності відмірювання інтервалів, кожна операція оцінюється ретроспективно, тобто досліджуваний інтервал багаторазово порівнюється з еталоном, що зберігається в пам'яті. Згідно 3 припущеннями вчених, цей етап $\epsilon$, по суті, водночас і виконавчим, і контрольним, у реалізації якого пріоритетну учать беруть другий та третій функціональні блоки, за А. Р. Лурія.

Відомо, що люди відрізняються по тому, як вони сприймають час. Так, одні мають стійку тенденцію переоцінювати його (брадихроністи), а інші - недооцінювати часові інтервали (тахіхроніти). Згідно з результатами наших досліджень, обстежувані-«сови» переважно тахіхроністичні особи, тоді 
як обстежувані-«жайворонки» - брадихроністичні. Така закономірність особливо виражена при сприйнятті часових проміжків у 30 сек. та 60 сек.

Літературні дані свідчать, що особи, які нараховують 60-65 сек. мають хороші адаптаційні можливості до різноманітних навантажень (фізичних та психічних), тоді як переоцінка часу (46-50 сек.) характеризується поганою адаптацією [7]. Таким чином, згідно з результатами наших досліджень, «сови» мають кращі адаптаційні можливості, ніж «жайворонки», яким властива переоцінка часу.

Висновки та перспективи подальшого дослідження. Оцінка сприйняття часових відрізків обстежуваних певною мірою залежала від типу біоритму та етапу дослідження. На першому етапі коефіцієнт точності був вищим у підгрупі «жайворонків», незалежно від часових проміжків. Серед цієї групи обстежуваних не виявилося осіб, які б переоцінили заданий часовий відрізок, тобто осібтатихроністів. На другому етапі дослідження при сприйнятті коротших часових відрізків, коефіцієнт точності був вищим у підгрупі, яку складали «жайворонки». Триваліші часові відрізки «сови» оцінили більш точно, ніж «жайворонки», серед яких переважна більшість обстежуваних осіб переоцінили часовий інтервал. Третій етап дослідження показав, що коефіцієнт точності при сприйнятті різних часових відрізків був вищим у підгрупі, яку складали «сови», серед яких виявилися лише особибрадихроністи. У підгрупі, яку складали «жайворонки», більшість осіб недооцінювали заданий проміжок часу, тобто вони $є$ тахихроністами.

У перспективі плануємо дослідити сприйняття коротких та довготривалих часових проміжків обстежуваних з різним рівнем тривожності.

\section{Джерела та література}

1. Багрова Н. Д. Фактор времени в восприятии человеком / Н. Д. Багрова. - Л. : Наука, 1980. - 150 с.

2. Божкова В. П. Сравнение характеристик плавного прослеживания у праворуких и леворуких людей / В. П. Божкова, Н. С. Суровичева, Д. П. Николаева // Физиология человека. - 2010. - Т. 36, № 6. C. $48-54$.

3. Возрастная психология / М. В. Гамезо, В. С. Герасимова, Г. Г. Горелова, Л. М. Орлова. - М. : Ноосфера, 1999. C. $115-145$.

4. Генетические основы восприятия времени у спортсменов / Г. В. Портнова, О. В. Сысоева, Н. В. Малюченко и др. // Журн. высш. нерв. деят. - 2007. - Т. 57, № 4. - С. 450-460.

5. Геодакян В. А. Эволюционные теории асимметризации организмов, мозга и тела / В. А. Геодакян // Успехи физиол. наук. - 2005. - Т. 36, № 1. - С. 24-53.

6. Дмитриев А. С. Ориентировка человека во времени (осознанная оценка коротких интервалов времени) / А. С. Дмитриева // Успехи физиол. наук. - 1980. - Т. 11, № 4. - С. 47-67.

7. Лютова Е. К. Развитие личности и креативности школьников с различными уровнями и структурными характеристиками интеллекта : автореф. дис. ... канд. психол. наук / Е. К. Лютова. - СПб. : [б. и.], 2000. -20 c.

8. Подвигина Д. Н. Характеристика процесса восприятия коротких интервалов времени / Д. Н. Подвигина, В. А. Ляховецкий // Журн. высш. нерв. деят. - 2010. - Т. 60, № 4. - С. 430-437.

9. Практикум із загальної психології / за ред. Т. І. Пашукової. - К. : Знання, 2000. - 204 с.

Швайко Светлана, Дмитроца Елена, Журавлев Александр. Влияние хронотипа на восприятие временных отрезков обследуемыми в разные периоды суток. Изучали уровень восприятия коротких временных отрезков лиц юношеского возраста с разным типом суточной активности. Установлено, что восприятие временных отрезков разной длительности у обследуемых с разным хронотипом зависит от времени суток. В утренний период суток результаты исследования оказались точнее в группе «жаворонков»; среди обследуемых этой группы не оказалось лиц, которые переоценили заданный временной отрезок. В обеденное время при восприятии коротких временных отрезков коэффициент точности был выше в подгруппе , которую составляли «жаворонки»; длительные временные отрезки «совы» оценили с большей точностью. В вечернее время суток коэффициент точности при восприятии разных временных отрезков был выше в группе «сов»; среди «жаворонков» большинство лиц недооценивали заданный промежуток времени.

Ключевые слова: хронотип, «жаворонки», «совы», время суток, временные промежутки.

Shvayko Svitlana, Dmytrotsa Olena, Zhuravlov Oleksandr. The Impact of Chronotype on Time Intervals Perception in Various Day Parts. In article were studied the perception of short time intervals by adolescents with different types of daily activity. We established that the perception of time intervals of varying duration in persons with different types of daily activity depends on the time of day. In the morning results of the investigation were more accurate in the «lark» group, there weren't people who have overestimated the specified time interval in this group. At lunchtime, the accuracy rate of shorter time intervals perception was higher in the «larks» subgroup; «owl» rated with 
greater accuracy longer time intervals. In the evening accuracy rate of different time intervals perception was higher in the «owls» group; most people in the «lark» subgroup underestimated the preset time intervals in the evening.

Key words: chronotype, «larks», «owl», day parts, time intervals.

Стаття надійшла до редколегії 09.04.2015 p.

УДК 612 - 796.41

\section{Вікторія Шишкевич Микола Гайдай}

\section{Особливості реагування серцево-судинної системи на ортостатичну пробу у гімнастів різної спортивної кваліфікації}

Досліджено й проаналізовано показники центральної гемодинаміки у 60-ти гімнастів чоловічої статі віком 13-15 років під час виконання активної ортостатичної проби. Виявлені величини основних показників гемодинаміки та реакції серцево-судинної системи на активну ортостатичну пробу залежно від рівня спортивної кваліфікації. Так, достовірно менші показники пульсового тиску, хвилинного об'єму та загального периферичного опору у майстрів спорту засвідчують економізацію роботи серця у спокої порівняно 3 першорозрядниками та кандидатами у майстри спорту.

Динаміка змін показників гемодинаміки при виконання ортопроби і періоду реституції показала, що домінантним типом гемодинаміки на навантаження виявився гіпотонічний тип, який властивий видам спорту, що розвивають витривалість, зокрема гімнастиці. Швидкий період реституції у майстрів спорту вказує на кращу адаптованість до фізичних навантажень зі зростанням спортивної кваліфікації.

Ключові слова: показники серцево-судинної системи, гімнасти, спортивна кваліфікація, ортостатична проба, тип гемодинаміки.

Постановка наукової проблеми та ії значення. Розвиток ролі дитячо-юнацького спорту призводить до підвищення вимог до спортсменів протягом усього періоду підготовки, ранньої спеціалізації, збільшення обсягу й інтенсивності тренувальних і змагальних навантажень юних спортсменів, що впливає не лише на рівень спортивних досягнень, а й на здоров'я [2]. Тому важливою і актуальною проблемою сучасного етапу розвитку дитячо-юнацького спорту є збереження і зміцнення здоров’я дітей та підлітків у процесі спортивної діяльності [5; 7, с. 14]. Дослідженню діяльності серця та стану центрального кровообігу залежно від впливу фізичного навантаження у спортсменів присвячено чимало робіт дослідників $[1 ; 3 ; 13]$. Одні науковці більшу увагу приділяли реагуванню артеріального тиску [9; 12], інші - ставили акцент на змінах частоти серцевих скорочень, що $є$ варіативною ознакою залежно від характеру зміни діяльності, змінам серцевого викиду, загального периферичного опору судин [10; 11]. В інших дослідженнях виявлено залежність параметрів центральної гемодинаміки від спрямованості тренувального процесу $[4 ; 6 ; 8$, с. $11 ; 14]$.

Враховуючи те, що показники гемодинаміки у стані спокою можуть бути недостатньо інформативними для характеристики потенційних функціональних можливостей серцево-судинної системи (CCC), використання активної ортостатичної проби дає змогу оцінити функціональний стан ССС спортсмена певної спортивної кваліфікації та виявити порушення у регуляції іiі діяльності.

Тому мета нашого дослідження - визначити реакції серцево-судинної системи при виконанні активної ортостатичної проби у хлопчиків 13-15 років, що займаються спортивною гімнастикою.

Матеріали та методи. У дослідженні взяло участь 60 гімнастів чоловічої статі Херсонського вищого училища фізичної культури (ХВУФК) 13-15 років із кваліфікацією: I розряду, кандидата у майстри спорту (КМС) та майстра спорту (МС). Стаж занять спортивною гімнастикою $-5-10$ років. Дослідження проведено на базі Херсонського обласного центру здоров’я та спортивної медицини. Для розв'язання завдання виявлення реакцій серцево-судинної системи на навантаження використано активну ортостатичну пробу. Вона дає змогу виявити адекватність регулювального впливу нейрогуморальних систем і реакції ССС, компенсуючи переміщення крові у нижні відділи судинного русла. Методика проведення функціональної проби включає: після інструктажу спортсмен 10-15 хв про-

(C) Шишкевич В., Гайдай М., 2015 